July 2011

\title{
Collaborative Scholarship in Library and Information Science
}

Suzanne Scott

San Jose State University, sue@sascott.ca

Follow this and additional works at: https://scholarworks.sjsu.edu/ischoolsrj

Part of the Library and Information Science Commons

\section{Recommended Citation}

Scott, S. (2011). Collaborative Scholarship in Library and Information Science. School of Information Student Research Journal, 1(1). https://doi.org/10.31979/2575-2499.010101 Retrieved from https://scholarworks.sjsu.edu/ischoolsrj/vol1/iss1/1

This article is brought to you by the open access Journals at SJSU ScholarWorks. It has been accepted for inclusion in School of Information Student Research Journal by an authorized administrator of SJSU ScholarWorks. For more information, please contact scholarworks@sjsu.edu. 
Professionals in the discipline of library and information science, if they are to drive discourse of and action resolution to the issues of discovery, access, and preservation of critical information and new knowledge, must actively promote their expertise through evidenced-based research, scholarship, and communication. The decision made by the School of Library and Information Science at San José State University to publish a graduate student journal is one way to promote this accord. For those conducting research and those who aspire to, the literature review - representing both what has occurred and the formulation of what can be - underpins the advancement of library and information science graduate scholarship.

The inaugural issue of $S R J$ opens with an invited contribution written by Dr. Anthony Bernier, Associate Professor with the School of Library and Information Science at San José State University. Reaching Escape Velocity and the Purpose of SLIS Student Research Journal embodies the commitment of our editors to promote evidenced graduate work about current topics in the fields of library and information science, records and archive management, and museum studies. If there were to be a Bernier 'brand' it should surely be marketed as driving escape velocity. Bernier presents an appealing perspective of the deep engagement a researcher has with a particular subject, and outlines the research paradigm by describing the steps to prepare a secondary research literature review. A scholar asks critical questions, surveys and reviews relevant texts, formulates a thesis, prepares evidenced analysis, and articulates, in their own words, a proposal or new direction to advance the knowledge of a field. All elements of critical inquiry are intrinsically linked by its core thesis; it's as straight a path as any.

Three graduate student articles submitted to the journal stood out among several peer-reviewed, as having met the criteria of graduate scholarship described by Bernier (2011). These authors present the reader with core questions, fluid sections of evidenced review of literatures, and suggestions to advance an idea or practice forward. Each author has a distinctive voice, and all are clearly passionate in their interpretation of the issues impacting their respective field of study. Independently, each author has targeted a central thesis that collectively I express to the library information science community is this: there is a need for greater collaboration. Collaboration that moves beyond the license agreements or the dashed lines of hierarchical charts to the model Peters (2009) terms "open knowledge production" (p. 142), taken deliberately as a creative, asynchronous, and reflective development process to advance our collective understanding of what can come next. Such is the essence of graduate scholarship that these authors offer to making a critical turn toward reaching escape velocity. 


\section{SLIS Student Research Journal}

July 2011, Volume 1, Issue 1

In Discovery Tools and Local Metadata Requirements in Academic Libraries, Mary Wood examines the effectiveness of current metadata creation practices evident in the academy to represent unique local collections. Woods' (2011) imparts a technical perspective on the need of academic librarians to evaluate metadata quality standards, in particular to ensuring access for users to discover special collections and institutional repository materials. Her review of current research about system interoperability and content limitations show "collaborative, incremental metadata creation processes are imperative" (p. 10) to ensuring quality and optimizing the discovery of local resources. Woods' sees opportunities to transform existing standards, and to create new best practices in digital resources management. This article highlights the challenges faced by library personnel to ensure discovery tools are effective, so in turn, they may successfully influence the research community to utilize its valued resources.

Mary completed her MLIS in May 2011, and works at Palo Alto University in California, where she is recently appointed as a Technical Services Librarian.

Antoinette Baker investigates the emergence of social media archives in Ethical Considerations in Web 2.0 Archives. In an era defined by an online 'public sphere', freely assessable personal productions intersect the tenets of intellectual property and protection of privacy and space. Archival practice is commonly understood as collecting and preserving historical accounts and artifacts deemed of 'societal value'; but what of individuals' personal media - their social pages, Tweets, and blogs authored in the public domain - do the same rules apply? Our personal communications medium is mass media, used regularly by school children and presidents alike; a mesh of societal history with the prosaic exchanges of routine life that raise questions examined by Baker (2011): What is a record of 'societal value'? Who has rights to manage the collection, preservation, and dissemination of personal media into the future? Is the legal donation by social media company Twitter, of the publics' communications to the Library of Congress, without third-party consent, ethical? Baker draws attention to professional ethics codes that "[empower] archivists to negotiate with donors" (p. 2) in constructing agreements that ensure ethical obligations are met when collecting and preserving personal collections. Her review may elicit discourse of the merits of Web 2.0 archives, and the role of archivists to educate and influence society to take care in the protection of its third-party privacy.

Antoinette began her MLIS in 2010, and is a part-time student and an attorney in private practice.

Joseph Andrews Jr. reviews the currency of health information resources in Collection Development of HIV/AIDS Information Resources in American Libraries. His is a compelling review of apparent voids in library collection 
policies and practices that could otherwise provide services to meet the information needs of two high-risk communities that contract HIV/AIDS. Andrews (2011) synthesizes a chronology of decisions evident within the library community that have influenced the development and advocacy of HIV/AIDS information resource collections. In outlining the availability of sexually explicit health information he found underlying conflict among practitioners to providing access to relevant resources while conforming to certain or perceived societal norms. His analysis reflects an embarrassing reality that marginalized groups in society do not always know how to find and then interpret critical information resources. From reading Andrews (2011) one may wonder whether the ethos of public librarians to strengthen relationships with all library users will embrace "involving community members in the collection development process" (p. 9) as a means both to improve relevancy of its services, and to help develop literacy skills that may benefit all.

Joseph is a second year MLIS student, and works as a copy cataloguer at the University of California, Los Angeles.

These authors identify specific concerns among a breadth of issues and events that intersect our domains of knowledge. Explicit connections among these works may be relevant to not only the library information science community, but to all audiences. As we know of our online environment information can be ephemeral, presenting challenges to source and exchange credible, valued information. Our electronic ecology establishes "relationships between documents" (Borgman, 2000, p. 98), wherein "references become actionable items" (ibid) that connect a reader with author. In one nondescript moment a reference that Andrews had trusted disappeared. Does removal of a source signal a change in its value? Has the information been updated or re-located? Does the content creator (or provider) no longer authenticate the work? These fundamental concerns about information access and its relevancy, currency and accuracy, are core values that ground the discipline of library and information science. How are information professionals to begin ascription of metadata for information discovery detailed by Woods (2001), or to contemplate design of proactive archival practices described by Baker (2011), if access to an authoritative source acknowledged by Andrews (2011) is not to be persistent? How will critical trust among people, and of their productions, be established and sustained in our digital communities?

The discourse and resolution to these issues is advancing in multivariate initiatives across a breadth of scholar and professional communities. Work focused on resource sharing, persistent access to digital information, data rights management, and content preservation, to name a few. The cooperation evident among researchers and practitioners and in partnerships with commercial 


\section{SLIS Student Research Journal}

July 2011, Volume 1, Issue 1

enterprise to design sustainable infrastructures for digital information (Borgman, 2000) will surely address some of the concerns articulated by the authors published here. If the reader also draws a linkage between these works, any proposal to enhance relationships and evolve greater collaboration among our interdisciplinary endeavors is advanced.

Suzanne Scott, Editor-in-Chief

SLIS Student Research Journal

San José State University

\section{References}

Borgman, C. L. (2000). From Gutenberg to the global information infrastructure: Access to information in the networked world. Cambridge, MA: MIT Press.

Peters, M.A. (2009). Education, creativity and the economy of passions. In Peters, M.A., Marginson, S., \& Murphy, P., Creativity and the global knowledge economy (125-147). New York: Peter Lang. 